\title{
Exploitation of the Small Whales in the North Atlantic
}

\section{By Arthur G. Bourne}

For several hundred years the small whales of the North Atlantic and the Mediterranean and Black Seas have been hunted with varying degrees of intensity. All too often the story has been one of overhunting followed by rapid decline of stocks, but so little is known about these small whales that today it is impossible to assess their populations or the effects of present hunting on the stocks. The author recounts the history of eight species of small whale and urges the need for more research to ensure planned cropping of a valuable resource. A Canadian proposal for whale hunting as a sport is perhaps a sign of a new danger to come.

THE density of the animal populations of the North Atlantic and the Arctic is one of the highest on earth. For thousands of years man has exploited this abundance, with the result that wholesale slaughter is today leading to the near extinction of at least three of the world's largest mammals.

The area under discussion extends from latitude $30^{\circ} \mathrm{N}$ (Canary Islands) to the pack-ice of the Arctic, and from the North American continent to the European land-mass in the east, including the Mediterranean and Black Seas. In this region the warm oceanic currents from the south mixing with the cold counter-currents from the north produce the concentration of nutrient salts which supports a rich planktonic flora and fauna, resulting in this abundance of fish and marine mammals. The Norwegians were almost certainly the first to exploit this vast reservoir of food. As early as 890 Alfred the Great had heard of the whalermen of Tromsö, and by the 11 th century the Basques were operating in the Bay of Biscay; in the 17th century the English and Dutch followed suit, and at that time the Arctic and northern North Atlantic were reported to be "teeming" with whales.

The North Atlantic and Arctic whaling reached its zenith in the 17 th and 18th centuries. The industry was based on the North Atlantic right whale Balaena glacialis and the Greenland right whale $B$. mysticetus but, through over-fishing, first one then the other was brought to the verge of extinction. Today the North Atlantic right whale is extremely rare, if it survives at all, but the Greenland right whale, under protection, seems to be making a slow recovery. (One unspecified right whale, possibly a North Atlantic one, was caught in 1959 by the sperm whalers off Madeira.)

Of the five whales of economic importance, only one, the minke or pike whale Balaenoptera acutorostrata, one of the rorquals, is a small whale; the other four are the three other rorquals, the fin whale $B$. physalus, the sei whale $B$. borealis, and, until recently, the blue whale 


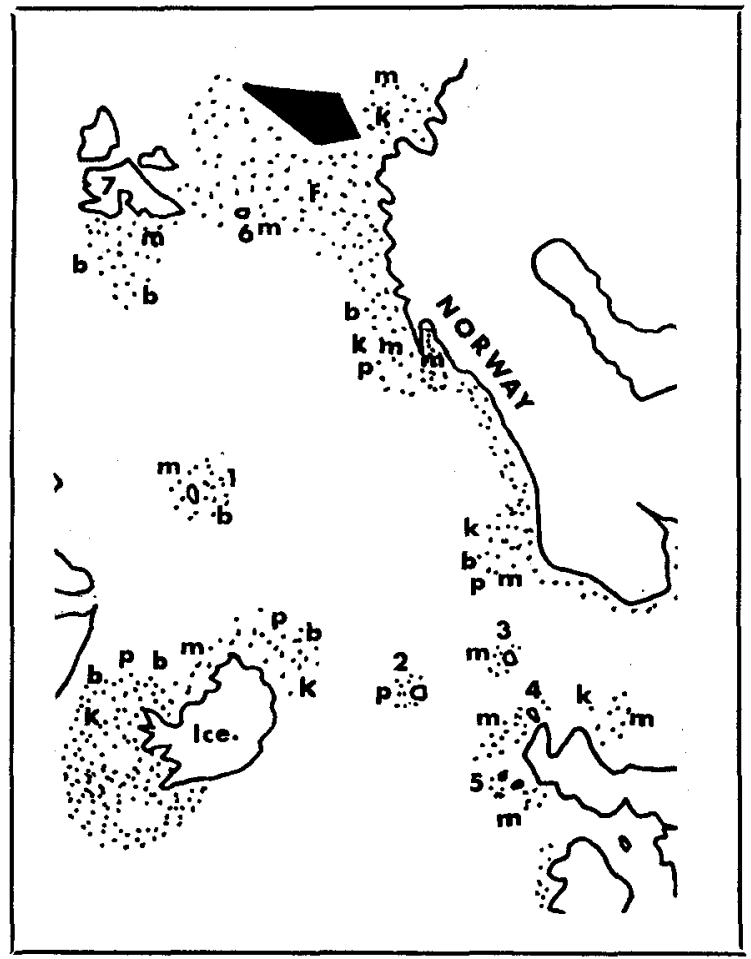

Whaling grounds for Small Whales in the

North-East Atlantic and the Arctic.

1. Jan Mayen

2. Faroes

3. Shetland

4. Orkney

5. Hebrides

6. Bjørnøya

7. Spittsbergen

$\mathrm{m}=$ Minke Whale.

$k=$ Killer Whale.

$\mathrm{b}=$ Bottle-noised

Whale.

$p=$ Pilot Whale.

B. musculus, together with the sperm whale Physeter catodon. When it became uneconomic to hunt the blue whale alone, it was hunted along with the fin whale, until in 1955 it was given complete protection for five years, renewed in 1960 and again for a further five years in 1964 .

During the eighteenth century the whalers out of New England turned their attention to the sperm whale, and in the first half of the nineteenth century this industry reached its peak with an annual average (in all seas) of 10,000 whales. From the middle of the century onwards, the industry declined, mainly for economic reasons rather than through a scarcity of whales. But Svend Foyn's invention of the harpoon gun in 1868 , and the introduction of steam power, made whaling once again a major industry. The whalers could now catch the faster but much larger rorquals, and by the early years of this century their numbers too had been seriously reduced.

Throughout these years the small species of whales had been taken on a small scale all along the coasts on both sides of the Atlantic and among the islands. Today organised whaling occurs at a number of land stations operating catchers in the adjacent sea areas. The total catch at all North Atlantic stations is some 47,778 barrels of oil, which represents about 1,400 whales of various species. In the Azores there 
Whaling grounds in the North-West

Atlantic,

Denmark Straits and Baffin Bay area

$\mathbf{B}=$ Blue.
$\mathbf{K}=$ Killer.
$\mathrm{P}=$ Pilot.
$\mathbf{b}=$ Bottle-nose.
$\mathrm{m}=$ Minke.

$W W=$ White

$\mathrm{N}=$ Narwhal.

$\mathrm{H}=$ Humpback.

Sei $=$ Sei.

F $=$ Fin.

Sp. $=$ Sperm.

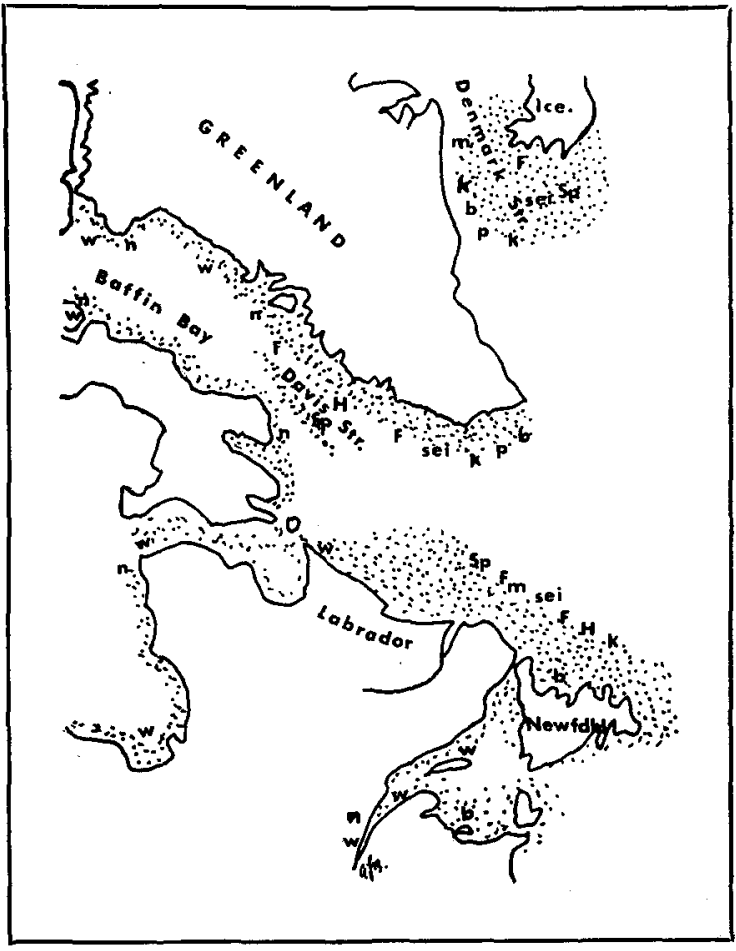

is a sperm whale fishery using open boats and hand harpoons, a survival from the earlier days of whating. Their catch for 1963 was 472 whales, which yielded 13,510 barrels of oil. There are a number of small industries based on the bottle-nosed whale Hyperoodon rostratus and the pilot whale Globicephala melaena, and the various aboriginal industries carried on by the Eskimos and North American Indians based principally on the beluga or white whale Delphinapterus leucas and the narwhal Monodon monoceros, with traditional or slightly modified methods. Other species are taken by the minke whale catchers, especially the bottle-nosed and the killer Orcinus orca.

Small whales have been defined by Jonsgård as those species which, when fully grown, are less than about twelve metres in length. This allows only two of the ten species of baleen whales to be designated small whales, and of these only the minke whale occurs in the North Atlantic and Arctic; the other, the pigmy right whale Neobalaena marginata is in the southern hemisphere. Of the toothed whales, the sperm whale is the only one that belongs to the larger whales; all the others belong to the small whale category. The killer whale Orcinus orca which is taken by the minke whale boats and occasionally by others, is sometimes destroyed because of alleged damage to fishing 


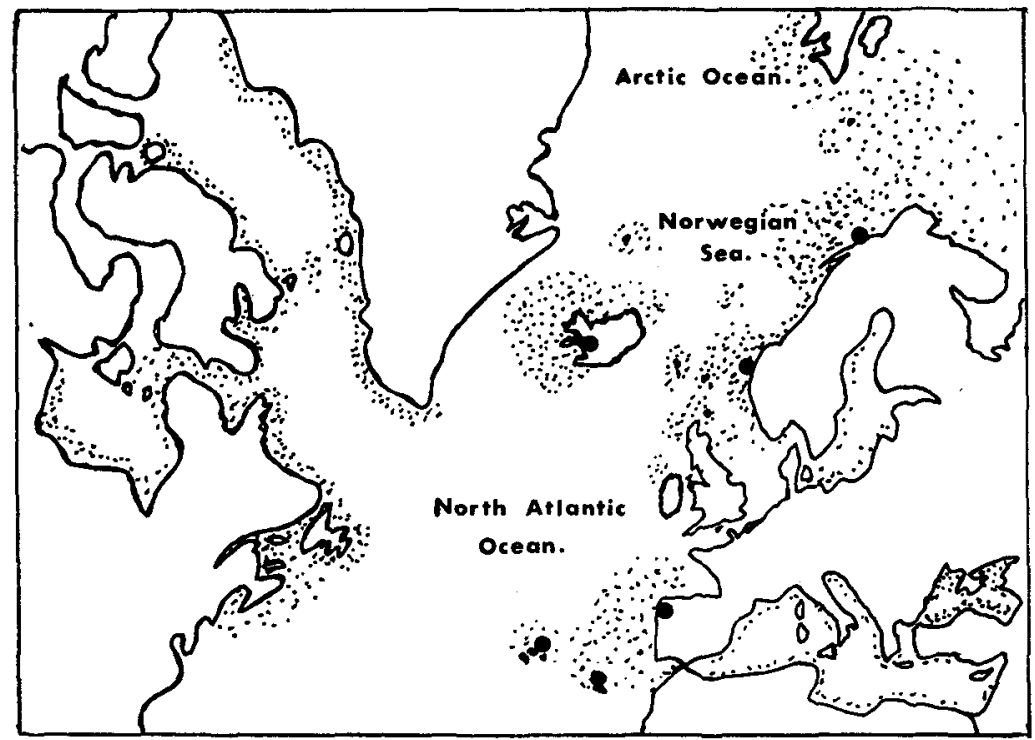

Whaling grounds in the North Atlantic and Arctic Oceans.

9 : Commercial Whaling Stations in operation in the North Atlantic.

nets and for driving off fish. Although small whales are occasionally taken by the catchers employed in the big whale fishery the numbers are very small, except in Spain where they form an appreciable catch. The total catch under this heading, exoluding Spain, for the six years ending in 1963 was only four, three of which were bottle-nosed, and one minke. The Spanish catch in the same time was 293, all of which were unspecified baleen whales; if these were small whales presumably they were minke.

Besides the minke, eight small whales have been actively exploited: the pilot, the bottle-nosed, the beluga, the narwhal, the killer, the white-sided dolphin Lagenorhynchus acutus, the white-beaked dolphin $L$. albirostris, and the common porpoise Phocaena phocoena. The minke is the most important, but the killer, pilot, bottle-nosed and white whales have been hunted regularly.*

\section{The Pilot Whale}

The pilot whale has been hunted for hundreds of years. Its habit of moving in large schools and frequenting bays and fjords has made it an easy prey for fishermen, and it is the basis of an important industry in the Faroes, Norway, the Denmark Straits and Newfoundland; it used also to be taken in the Shetlands, the Orkneys and the

* A paper on the minke whale by the author will appear in the next issue of ORYX (April 1966). 
Pilot

Whale

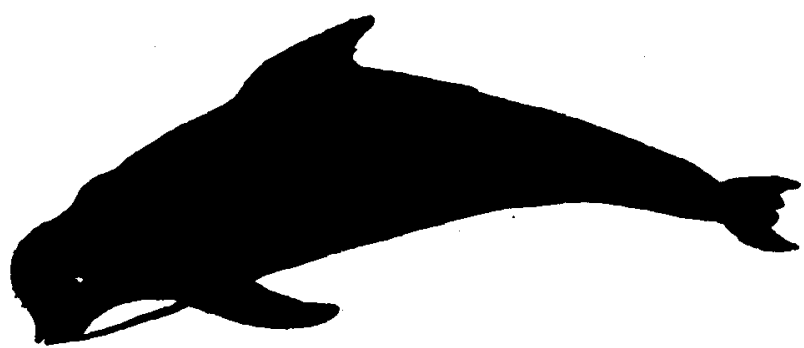

Hebrides. In the Faroes, it is driven into shallow waters and slaughtered. Between 1584 and 1883 over 117,000 were killed in this way, and even in recent years over 1,000 have been taken in a single season. In Newfoundland the annual catch is between 3,000 and 4,000, most of which are used as feed on the mink farms. A few pilot whales are also taken by the Norwegian minke whalers, 71 in 1963, though the average annual catch for the five years ending in 1962 was 221.2. There is insufficient data to say whether the pilot whales in the North Atlantic are decreasing; it is possible that they might become scarce locally through overfishing, but this depends on whether the various stocks are isolated. If they are, the Newfoundland stocks could one day be endangered.

The Bottle-nosed Whale

The Scots began hunting the bottle-nosed whale in 1877. They were closely followed by the Norwegians about 1880 along with their sealing activities. This developed into an independent industry; by the $1890 \mathrm{~s}$ over 70 vessels were catching an average annual crop of about 3,000 whales, but by the end of the 1920 s this industry was finished. A few are still taken by Norwegian land stations and also as a supplementary catch by the minke boats. Between them their average catch of bottlenosed whales for the four years ending in 1963 was 216; in 1963 it was 267. This whale is still taken off West Greenland, the Gulf of St. Lawrence, the Faroes and Iceland.

The Beluga

For hundreds of years the Eskimos and, later, Europeans have hunted the beluga (or white whale) for its hide and blubber; the

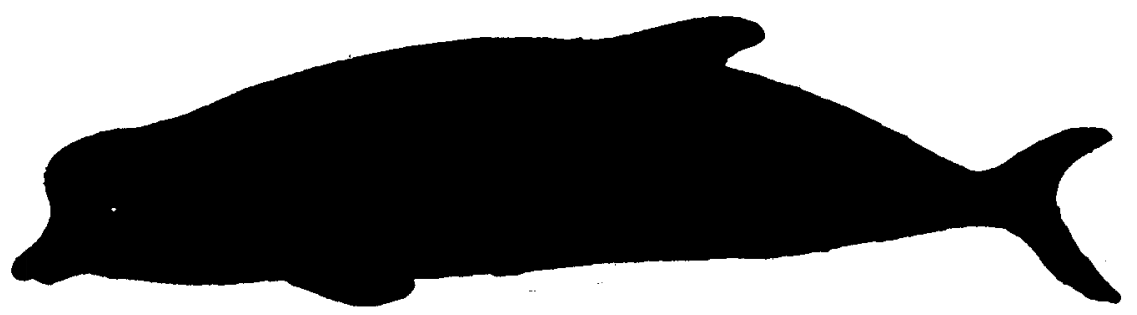

Bottle-nosed Whale 
Hudson Bay Company began beluga whaling in 1688 . In early summer the Eskimos wait until the whales are driven up the leads in the seaice by killer whales and then kill them with hand-harpoons from the ice or from kayaks. The whales are also caught with nets and harpoons in the Gulf of St. Lawrence and off west Greenland. Towards the end of the 19th century the Norwegians were taking an average annual crop of 2,000 belugas off Spitzbergen. By the turn of the century this area was overfished and the industry ceased. The hide, sometimes called "porpoise-hide", is much valued for its toughness and is used for making leather. The flesh is used both for human consumption and for feeding sledge-dogs, while the blubber provides oil.

At one time, Indians on the St. Lawrence used to trap the belugas as they migrated up the river. Recently this trap has been reintroduced to capture the whales for oceanaria and marinelands. In the US belugas have been successfully kept in captivity, and the recent proliferation of oceanaria and marinelands on both sides of the Atlantic could become a factor in the depletion of stocks if, as a result of unskilled keepers and inadequate facilities, frequent replacements had to be made. Such demands would be wasteful, rather than a threat, to the species, but there is cause for alarm over the project of the Manitoba Government to develop beluga hunting at Churchill on the Hudson Bay in the hope of earning dollars from United States sportsmen. This would make the port of Churchill a tourist centre and producer of whale by-products. The sportsman who landed the whale would receive a Government trophy consisting of the animal's jawbone mounted on a plaque, and the carcase would be taken to the factory. The hunters would have to hire local guides, who would also receive the money realised on the carcases. Such an industry could constitute a real threat to the belugas, and if the "sport" were to catch on it could spread throughout their range in North America, and eventually involve other species, particularly the narwhal, which has a better trophy to offer. Figures from Greenland show that during the 1962-63 season (the last for which they are available), the total catch of belugas from all areas was 575 .

\section{The Narwhal}

The Eskimos catch the narwhal in considerable numbers, usually with the beluga with which it often associates. It is caught throughout the Davis Strait and Baffin Bay areas and in the Hudson Strait and Hudson Bay. The skin is a rich source of vitamin C-100 grams of skin can yield $31.8 \mathrm{mg}$. of the vitamin-and the Eskimos extract this by chewing the raw skin; they eat some of the meat but most of it is given to the sledge-dogs. No figures are available to show the number of animals killed, except for the Greenland fishery, where the total catch from all areas in the 1962-63 season was 351 .

\section{The Killer Whale}

The killer whale is taken as a supplementary catch by the large whale industry and by the minke whale boats out from Norway. The 


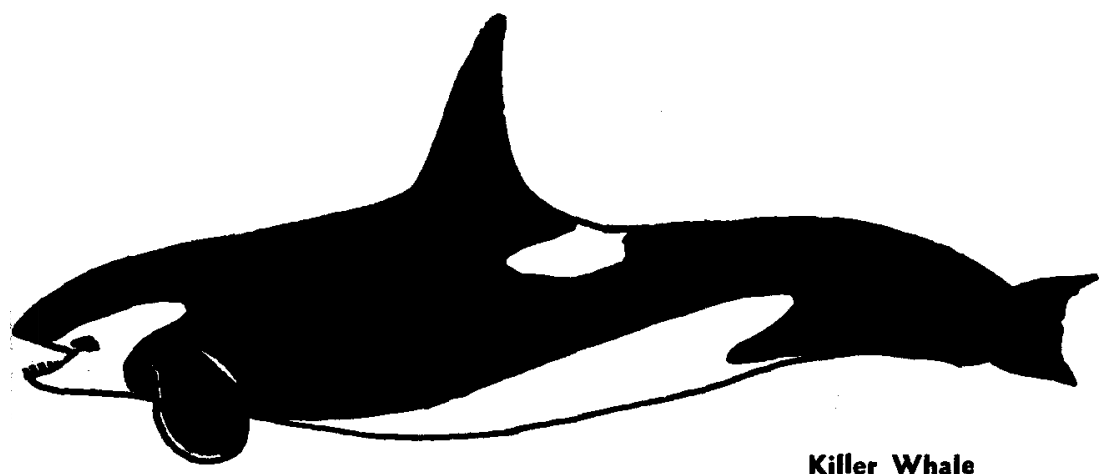

catches totalled 90 for the 1963 season, though the average for the last four years has been 107, the highest catch, 124, in 1962. There has been a tendency for the killer whale total to increase since 1954. It is more often shot on sight by fishermen because it scares away the fish shoals, as is the case on the Atlantic seaboard of Morocco where it scares away the bluefin tuna Thynnus thynnus from the fishing grounds.

\section{Porpoises and Dolphins}

Porpoises have always been caught when opportunity occurred. In the eleventh century they formed the basis of an important industry off the Normandy coast. So heavy was the fishing that a law was passed in 1098 setting limits to the catch, probably the first legal protection for cetaceans. The meat was highly esteemed, and featured on the menu at the coronation dinner of Henry VII. The oil was much in demand for burning and lighting. Today porpoises and dolphins are still taken almost throughout their range, especially in the Black Sea, and both are liable to be killed because of alleged damage to nets.

Porpoises and dolphins are common in the Mediterranean and the Black Sea, but the only organised fishery is that of Turkey. The abundance of dolphins in the Black Sea has led to a well organised fishery along the north and north-east Turkish coast, at the mouth of the Bosphorus and in nearby waters. Hunting is by rifle, but formerly nets were used as well. The season lasts from the middle of September until June; fishing is forbidden during the mating season from June to September. Yields in years of abundance have produced from 5,0008,000 tons; usually it is 3,000-5,000 tons, but there has been a drop in recent seasons. Elsewhere dolphins are killed along with porpoises and killer whales because of alleged damage to fishing gear. The annual loss per boat owner in France, for instance, averages about 2,000 francs: damage mainly to gillnets and trawls working at depths of 50 to 100 metres, done chiefly, it is reported, by dolphins and porpoises; in Italy it is about 300 million lire: sardine and other nets; in Spain, 20,000 pesetas: sardine nets; and in Yugoslavia, 20 million dinars. If 
the figures are accurate and the damage done can be firmly laid at the door of the cetaceans, obviously protective measures have to be taken. It is worth noting that Turkey, with its dolphin-based industry, does not seem to suffer from damaged nets. On the Mediterranean shores of Morocco dolphins do some damage to nets, but it is the killer whales that do the most damage by driving the bluefin tuna off the Atlantic coast. Various methods are used by different countries to combat this nuisance: rifles and sporting guns (with, as would be expected, little effect), underwater detonators and underwater grenades attached to nets, and poisons poured into the sea; the last, if they have any effects at all, would probably harm the fish and subsequently the human consumer more than the cetacean. Electric impulses, ultrasonics and a host of other methods are in use, including the most repulsive one of tying a wounded cetacean to the boat so that the escaping blood keeps the other cetaceans away. A new method, using the recorded distress calls of a wounded animal, is being tried. If this works then there is a chance of keeping the cetaceans away from the nets without actually harming them. The reason why there is no commercial exploitation except by the Turks is that there is no sale for porpoise and dolphin meat.

In the North Atlantic and the Arctic small whales form the basis of not inconsiderable local industries. However, it is impossible, with the data available, to say to what extent the various species (with the exception of the minke whale) are being cropped, and still less is it possible to say whether their populations can stand being hunted as intensively as at present. The operations by the Eskimos and other small scale industries are unlikely to have much effect on the stocks, but the more organised fisheries could affect both the local stocks and the total population, if it were proved that a population was being hunted at more than one station on its migration route.

\section{The Information is Inadequate}

The real need is for more research into the biology, population structure and movements of the small whale species. This knowledge and more information from the remoter whaling regions is essential before any real assessment of the total annual crops can be undertaken, and the rational management of the stocks be planned. Without knowledge of the populations, their inter-relationships in the different regions of this huge sea area, and migrations, no estimates of the possible sustained revenue can be made.

In the case of the more economically important minke whale, the Norwegians are doing research on population structure and movements, and studying the biology of some of the other species. For many species the only data available is in the records of the whaling companies and some of the small shore stations and research departments. Most of the data available is that supplied by the whale-boats, log-books, fishermen and coastal populations. Some information is available in the United Kingdom from some of these sources and from 



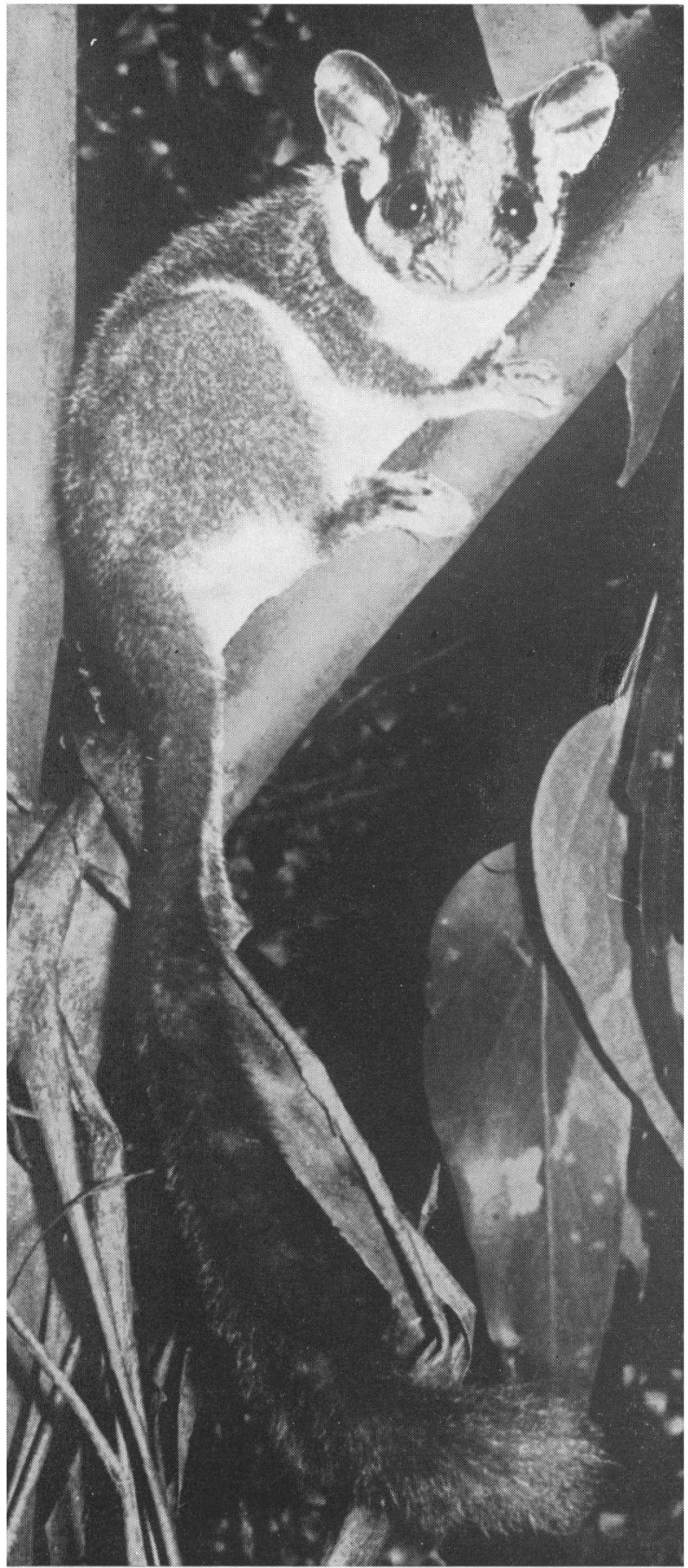

\section{LEADBEATER'S}

POSSUM

Plate 12: A marsupial of forest land in Victoria, Australia, thought to be extinct until in 1961 a small colony was rediscovered. It has since been seen in a few other areas. The habitat of the colony is considered safe for the moment. 


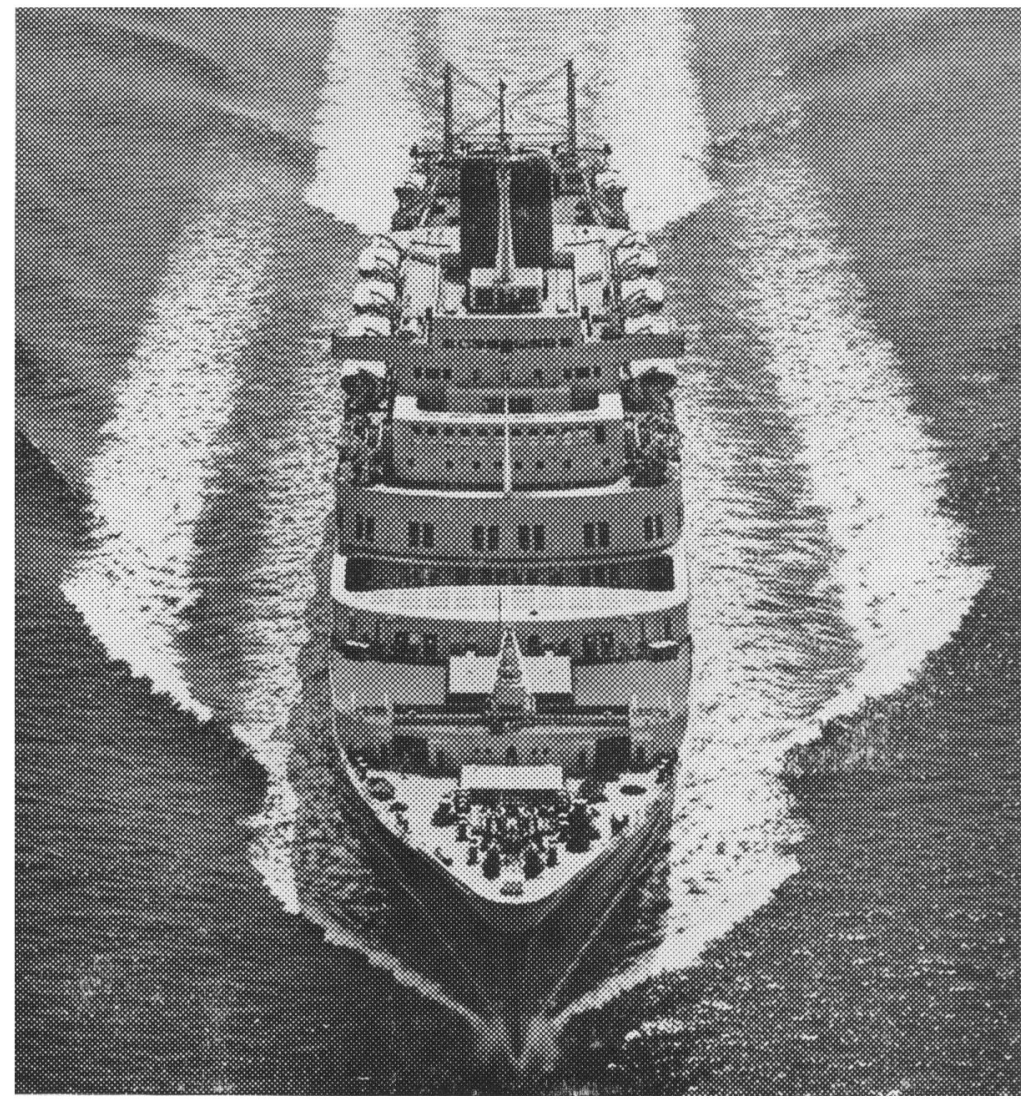

\section{Now, Fridays from Southampton TO CAPE TOWN IN UNDER 12 DAYS}

Union-Castle's Mail service between England and South Africa has been accelerated. Regular passenger sailings from Southampton on Fridays at 1 p.m: from Cape Town on Wednesdays at 4 p.m: calls always at Las Palmas, southbound and northbound, and sometimes Madeira as well. Details of this new service are in the new Fares and Sailings folder, obtainable from Travel Agents or from Union-Castle offices: at 19-21 Old Bond Street, London, W.1, and at Southampton, Birmingham, Leeds, Manchester, Glasgow, Cape Town, Port Elizabeth, East London, Durban, Johannesburg, Salisbury and Mombasa.

\section{the going's good by UMHON-CASTLLE \\ THE BIG SHIP WAY TO AFRICA}


the records of stranded whales published by the British Museum (Natural History).

In 1964 a whale recording scheme for the British sea areas was introduced to enlist the help of voluntary observers. By the end of the year over a thousand observers had volunteered, covering almost the whole of the coastline of the British Isles. Difficulties of identification, though by no means overcome, have been lessened by the introduction of a record card, and, by a process of elimination, it is possible to reduce the data down to species. Already it has given us a better idea of the distribution of the cetacea during the summer months.

SUMMARY

The North Atlantic and the Arctic whale stocks have sustained an industry of varying intensity for hundreds of years. The large whales have, as in other sea areas, taken the brunt, but the small whales have also been exploited intensely, and have been the basis of small coastal industries for the last 300-400 years, and in some cases even longer. Of the small whales the bottle-nosed, pilot and beluga whales have been most consistently exploited, and "fished-out" locally in some areas. In modern times the minke whale has been increasingly hunted, with the bottle-nosed and pilot whales taking a supplementary role. Although killer whales are also taken in the minke fishery they have had less attention than other species, probably because of their ferocious reputation. Dolphins and porpoises on the other hand have been valued from very early times and still form small supplements to the fishermen's catches, while in Turkey they form a well organised industry. There is insufficient data available to allow an assessment of the total population of the various small whale species, which could be a basis for a rational cropping scheme. There is an urgent need for more research, especially into the structure of the populations, their numbers and movements. Records except in a few cases are scanty, and where available are of sightings and killings only. Research is increasing and the recent whale-watching scheme in the UK is encouraging.

To discourage waste in marinelands and oceanaria, regulations governing the conditions in which these animals are kept should be introduced and enforced, and schemes such as the one introduced by the Government of Manitoba should be discouraged and where possible disallowed.

References

Sources for this paper include unpublished material and correspondence, much made available by Intertech, as well as published papers :

BOURNE, A. G. 1962, ORYX, VI.5.

JENKINS, J. T. 1921, A History of the Whale Fisheries.

JONSGARDM, A. 1955, Norsk, Hvalfangst-Tidende, 9 and 12.

JOHNSEN, A. D. 1957, Den Moderne Hvalfangst Historie, Vol. 1.

NEWMAN, R. 1963, Tor. G. \& Mail.

RAVEL, C. 1963, Stud. Gen. Fish. Comm. Medit., (22).

SAEMUNDSSON, B. 1939, Zoo. Iceland. 